\title{
Limitations to growth: social-ecological challenges to aquaculture development in five wealthy nations
}

Nathan Young, Camilla Brattland, Celeste Digiovanni, Bjorn Hersoug, Jahn Petter Johnsen,

Kine Mari Karlsen, Ingrid Kvalvik, Erik Olofsson, Knud Simonsen, Ann-Magnhild Solås, Helgi

Thorarensen

* Corresponding author: Nathan Young, School of Sociological and Anthropological Studies, University of Ottawa, Canada, nyoung@uottawa.ca

** Research for this article was conducted with support from the Research Council of Norway (grant number 11110).

*** This is a pre-publication version of an article appearing in Marine Policy in 2019. Please consult and cite the final version when it is available. 


\begin{abstract}
Aquaculture is a major contributor to global food production, but has attracted considerable controversy. Disagreements over the social and ecological impacts of aquaculture (positive and negative) have hindered further expansion of aquaculture production, particularly in wealthy democratic countries. This article presents findings from a series of workshops bringing international aquaculture scholars together from the natural and social sciences to examine and compare social-ecological challenges facing aquaculture development in five nations: Canada, the Faroe Islands, Iceland, Norway, and Sweden. This multinational comparison provides unique insights into common and particular challenges in aquaculture governance - a dimension that is missing in current literature about the industry. A political ecology framework from the environmental social sciences is used to examine how natural and human phenomena interact to shape these challenges and frame the conflicts that often result. The analysis reveals a wide range of social-ecological factors limiting aquaculture expansion in the five countries, including access to suitable environments, interactions with other sectors, and policy and regulatory gaps - not only with respect to aquaculture, but also on related issues such as marine spatial planning and the involvement of indigenous peoples in decision-making. The findings provide preliminary guidance for future policy development and comparative aquaculture research.
\end{abstract}

\title{
1. Introduction
}

Aquaculture, the farming of aquatic animals and plants for private harvest, has grown substantially in recent decades and now plays a major role in the global food system. Like landbased agriculture, aquaculture takes multiple forms, from the small-scale stocking of ponds with herbivorous fish for local consumption, to the industrial-scale production of high-value species such as salmon, shrimp, and shellfish for international markets (FAO 2016). Global aquaculture production has grown at rapid rate, from 32 million tonnes in 2000 to 77 million tonnes in 2015 (Zhou 2017). With this growth have come new social and ecological challenges. In developing regions where small-scale freshwater aquaculture is common, issues such as landscape change, water quality, deforestation, and loss of wetlands have been identified as key problems (Bush and Marschke 2014). In wealthier countries, controversy has emerged over impacts on wild stocks and species, degradation of habitat, rural futures and economic restructuring, and legal and moral rights to aquatic spaces and resources (Young and Matthews 2010). These challenges 
and disagreements vary substantially across different localities and regions, but they also share common themes. In many cases, social and ecological challenges are severe enough to cast doubt on the prospects for future expansion of this industry (e.g. Deutsch et al. 2007; Young and Liston 2010).

This article compares the social and ecological factors currently limiting aquaculture development in five wealthy nations: Canada, the Faroe Islands, Iceland, Norway, and Sweden. The comparison is the result of two international workshops held in 2015 and 2017 attended by the authors to investigate the challenges of aquaculture governance in each of these nations. The workshops were motivated by the observation that while much is known about the socialecological challenges limiting aquaculture development at the national scale, few international comparative analyses exist (see Bankes et al. 2016). International comparisons are critical for understanding commonalities and differences across political and environmental contexts, which allow us to distinguish among challenges of different scale and scope. Comparisons are also essential for policy learning (Bennett and Howlett 1992). If aquaculture governance is to be improved both regionally and globally, it is important to compare one's own challenges, experiences, and decisions with those taking place in other countries.

The five nation comparison is anchored in a political ecology framework. Political ecology is a flexible theoretical framework that examines the mutual influence that human and environmental factors have on one another (Robbins 2012). This framework conceptualises the relationship between humans and nature as both dynamic and constraining. For example, political ecologists argue that environmental conditions are profoundly influenced by human political processes characterized by ongoing material, discursive, and epistemological struggles (Biersack 2006). In turn, human politics are influenced, framed, and constrained by environmental factors, including natural and human-caused changes that are often the unintended result of past decisions. Political ecology is therefore a heterogeneous, historically-informed framework that attempts to bridge the conceptual divide between humans and nature, making it a powerful tool for examining conflicts over territories and natural resources (Belskey 2002).

The article proceeds as follows. The next section details the political ecology approach used in this analysis. The third section provides information on the methods employed in the workshops and afterwards to compare these diverse cases, including the limitations of this approach. The fourth section provides brief descriptions of the current state of the aquaculture 
sector in each nation. The fifth section provides findings from the analysis, drawing links across the countries and identifying key thematic convergences and differences in social and ecological variables. The fifth section concludes with a discussion of lessons learned for both aquaculture governance and for future comparative aquaculture research.

\section{A political ecology framework for understanding conflict and disagreement}

Researchers use political ecology to investigate the intersection of human and natural systems, focusing in particular on "the way that politics is inevitably ecological and that ecology is inherently political" (Robbins 2012: 3). The term political ecology, however, is conceptualized in multiple ways across the environmental social sciences (see Neumann 2005; Biersack 2006; Escobar 2010; Robbins 2012). For example, in some literature, political ecology is closely linked with the green politics or Green Marxist movements and therefore has a strong undertone of environmental justice (e.g., Atkinson 1991). Scholars working in this tradition examine how rules of access, management, and extraction of natural resources reflect and reinforce social relations (with particular emphasis on economic, gender, and normative structures). These intersecting social and ecological inequalities often lead to negative or unsustainable environmental outcomes, the effects of which are themselves unequally distributed in the form of pollution, degradation, and risk (Silver 2010). Political ecologists working in this tradition see conflicts over environment as intertwined with a range of material and symbolic social inequities. As such, the sources of political power and authority, such as property rights, science and expertise, and legal-judicial systems are also frequently cited as contributors to conflict and controversy (e.g., Forsyth 2003; Peet et al. 2011). The main criticism of this branch of political ecology is that it underplays the role of biophysical systems in shaping and maintaining human political systems. To paraphrase Walker (2005), it is unclear "where is the ecology in this political ecology" that places primary analytical emphasis on human practices, structures and meanings (see also Nygren and Rikoon 2008).

A second branch of political ecology focuses more on the iterative relationships between social and environmental variables and conditions. According to Turner (2014), this conceptualization of political ecology reflects a renewed interest among some social scientists in the role that environmental phenomena play in human affairs (see also Bennett et al. 2017). Turner contrasts political ecology with resilience theory, arguing that both are attempts to 
address the space in between the environmental and social sciences, nature and humans. While resilience theory extends from ecology to encompass people, political ecology extends from the social sciences to incorporate the biophysical environment. Both bring their biases into this middle ground - resilience theory is more attuned to systems thinking, while political ecology emphasizes history and context (Turner 2014). This branch of political ecology is less indebted to neo-Marxist thinking and more open to seeing nature as a semi-autonomous actor in human affairs, even though it does not go so far as to accept the human-nonhuman symmetry evoked in actor-network theory and other co-constructionist frameworks (Nygren and Rikoon 2008; Young 2015).

The analysis presented in this article draws on both branches of political ecology. As will be discussed in Sections 4 and 5, in some countries uncertainty about future growth in the aquaculture sector is driven primarily by environmental conditions (although politics and governance are immediately drawn in). In others, however, uncertainty stems from social and political disagreements playing out across a range of institutions (although these disagreements often concern environmental conditions and impacts). Indeed, the existing literature on regional and national political ecologies of aquaculture reflects both political ecology approaches, in some cases focusing on environmental conditions as a prompt for political action (e.g., Barton and Floysand 2000) and in other cases focusing on the role of political priorities and conditions in shaping territorial and environmental outcomes (e.g., Silver 2010). A flexible political ecology framework that draws on both traditions allows us to bring these different international cases together to provide at least partial explanations of the existence, absence, and character of particular conflicts.

\section{Methods}

This comparative study is based on a collaborative project involving the authors called Aqualog (Intensive aquaculture and sustainable regional development in the Arctic region - from controversy to dialogue). The Aqualog project brought together experts on aquaculture governance from each of the five nations for two multi-day workshop meetings, the first in Troms $\varnothing$, Norway, in April 2015 (Karlsen et al. 2015), and the second in Vancouver, Canada, in April 2017 (Hersoug et al. 2017). Some of the participants were university-based researchers, some were based in government research institutes, and some were with not-for-profit 
development agencies. Some held social science backgrounds while others had natural science training. The aim of these workshops was to bridge the national divides that often manifest in academic study of natural resource issues and lay the groundwork for comparative analyses of similarities and differences in aquaculture governance, policy, and public discourses across multiple countries. The workshops proceeded in two steps. The first step involved participants giving formal presentations of key findings from their regional or national research. The second step involved comparison and synthesis activities using seminar-style activities, so that specific points could be considered and debated by the group. Results were compiled into thematic tables emphasizing three main dimensions: ecological and biophysical issues, public and community issues, and institutional and governance issues. The thematic tables were then used to analyze how each issue might affect aquaculture production across the five nations, and to identify similarities and differences in how the issues are presently being addressed (if applicable) in each case.

Following the workshops, the authors conducted detailed reviews of policy documents and the academic literatures on issues and problems related to aquaculture production in their respective nations. The literatures and policy documentation were more extensive for some countries (e.g., Norway and Canada) than for others (e.g., Faroe Islands, Iceland, and Sweden), reflecting the scale of aquaculture production and the intensity of controversy. For all cases, the authors generated standardized summaries of how political-ecological dynamics manifest in their country of expertise. These were then shared and compared in electronically-mediated discussions in the weeks following the second workshop to generate the tables and comparative findings discussed in Section 5 below.

This method of using intensive workshops with academics and expert practitioners from a range of backgrounds to generate comparative findings has been used by a number of research groups addressing social-ecological questions and problems (e.g., Rudd et al. 2011; Fazey et al. 2012). The method is particularly well-suited to complex, multidimensional issues that are beyond the analytical grasp of a single researcher or the insights of a single disciplinary perspective. However, this method has limitations that must be acknowledged. Foremost is that the findings derived from this analysis are preliminary and by no means definitive. This article is based on the collective expertise of the authors and a comparative reading of existing literature and research activities within each nation. Ideally, this is but a first step towards more rigorous 
comparative research that will collect original data in a coordinated manner to directly contrast cross-national experiences using the variables identified below.

\section{Aquaculture in five wealthy nations: an overview}

Aquaculture is a catch-all term for a highly variable method of food production. In less developed regions of the world, aquaculture is predominantly a small-scale activity tied to local markets and subsistence activities (major exceptions include industrial-scale shrimp and tilapia production that takes place predominantly in the Global South). In wealthy countries, aquaculture is dominated by large, vertically-integrated corporate entities producing large volumes for international markets. Production is highly regulated, meticulously planned, and technologically-intensive. With the exception of Sweden, salmon farming is the most significant aquaculture activity (by volume and value) in the countries compared in this article. This section provides an overview of aquaculture activities and controversies in each of the five nations. The comparisons are then explored in Section 5 using the political ecology framework.

\subsection{Canada}

The Canadian aquaculture industry is diverse, with substantial production of both marine and freshwater species. Salmon aquaculture represents approximately $65 \%$ of Canadian production by volume, and $70 \%$ of the industry by value (DFO 2015). Nevertheless, salmon production is modest by international standards, as Canadian production is only $10 \%$ of Norway's by volume. Shellfish aquaculture has a significant presence on the Atlantic and Pacific coasts, with emphasis on mussels, clams and oysters. The most significant freshwater species is trout, but only accounts for $4 \%$ of total production by volume (DFO 2015).

Canadian governments, both federal and provincial, have been actively supporting aquaculture development since the early 1980s (Keller and Leslie 1996). Governments have seen aquaculture as an important tool for rural development, particularly as employment in fisheries

and coastal forestry have declined, and have been eager to capitalize on natural assets such as the country's vast coastline and favourable climate for rearing coldwater species (Young and Matthews 2010). Despite enjoying the unqualified support of government, the industry has been controversial since the beginning. Concerns about environmental impacts have been the most consistent theme in the Canadian controversy, particularly with respect to disease and pathogen 
transfer among cultured and wild species (Krkošek et al. 2007). On Canada’s Atlantic coast, several critically endangered wild stocks of Atlantic salmon (Salmo salar) migrate through waters of intensive aquaculture production, raising concerns about interactions. On Canada's Pacific coast, farmed Atlantic salmon are an exotic species that some see as a colonization threat (Keller and Leslie 1996). The Pacific region is home to significant wild salmon stocks and migrations that support a large commercial fleet, an extensive recreational fishing sector, and numerous First Nation (indigenous) fisheries. The wild salmon harvest has tremendous cultural and economic importance to First Nations people in the province of British Columbia. The rights of First Nations people across Canada are subject to ongoing political and legal challenges, and some see the siting of aquaculture operations without the consent of First Nations communities as a violation of traditional territories and a threat to subsistence activities such as clam harvesting (Young and Matthews 2010). Interactions with other coastal industries have also spurred conflict, particularly with the lobster fishery in Atlantic Canada, and tourism in the Pacific region.

Canadian federalism complicates aquaculture governance and regulation. The Government of Canada has jurisdiction over marine fisheries and oceans, while provincial governments have authority over natural resources and business licensing (Howlett and Brownsley 2008). This means that aquaculture is regulated by both levels of government simultaneously - a situation that has frustrated both proponents (who see many regulations as overlapping and redundant) and opponents (who see significant regulatory gaps and inconsistencies across jurisdictions). At the federal level, Canada has never enacted an Aquaculture Act or similar legislation specific to aquaculture, relying on fisheries, marine usage, and environmental assessment law to regulate the industry (Doelle and Saunders 2016). In response to political pressures, provincial and federal governments have initiated several public inquiries over the past several decades to hear testimony from citizens and experts (Cohen 2012). The result has been intermittent moratoria on aquaculture licensing, including a current ban on salmon aquaculture expansion into the northern half of British Columbia.

\subsection{The Faroe Islands}

Salmon farming dominates the aquaculture sector in the Faroe Islands, with production totaling 82,000 tonnes in 2016. Salmon aquaculture plays a large role in the Faroese economy, 
accounting for nearly 50\% of overall export values (SFI 2017). Indeed, the Faroe Islands produces the highest volume of farmed salmon per capita in the world, with approximately 1.6 tonnes per capita per year. Rainbow trout were grown prior to 2011, and in recent years there have been attempts to farm seaweed.

The Faroese government has been an active supporter of aquaculture development, seeing it as a natural extension of existing maritime industries. The Faroese people have a long tradition of harvesting from the sea, and the salmon farming industry enjoys widespread public support. Salmon aquaculture and traditional fisheries are also spatially separated, as nearly all commercial fishing is forbidden within 3 nautical miles of shore, where farms are located. Moreover, Atlantic salmon are not a native species in Faroese rivers, which reduces regular contact between farmed and wild populations. In recent years, however, some local coastal lobster fishermen have voiced concerns about ecological impacts from nearby salmon farms. Some tourism operators and leisure clubs have also recently criticized the aesthetic and ecological impacts of the industry.

Current law stipulates that aquaculture companies must be registered in the Faroe Islands, and the majority of the board and its director must be resident citizens. Regulations introduced in 2012 restrict a foreign interest from owning more than $20 \%$ of any single company (Jacobsen 2011). Despite these regulations, the industry has consolidated considerably since the 1980s, and there are only three major companies operating in the country today. The issue of foreign ownership and investment is the subject of ongoing political debate. Complicating matters is that consolidation is also changing the economic geography of the industry. While production is geographically dispersed across a range of coastal regions, land-based activities such as smolt production, processing, and support industries have been centralized, causing a redistribution of economic benefits away from some rural areas.

Faroese aquaculture faces some important ecological challenges. Compared with nations such as Canada and Norway, the natural geography of the Faroe Islands is limited. Salmon farming already occupies nearly all suitable locations on the Faroese coastline. Further expansion will require innovations in farming methods to reduce environmental impacts (thus allowing more density in farm siting), or the development of cage technologies capable of withstanding severe current and wave conditions (allowing for movement offshore). Disease is also a persistent concern. An outbreak of Infectious Salmon Anemia (ISA) in the early 2000s devastated the industry (Jacobsen 2011). Following this, the Faroese government enhanced 
oversight and monitoring of salmon farms, and implemented a new regulatory system based on geographically-defined management zones (MZ). Operations such as stocking, treatment, harvest and fallow period are to be coordinated within an MZ. While there are no specific limitations on the number of salmon reared within an $\mathrm{MZ}$ or site license (several of which may exist within an $\mathrm{MZ}$ ), regulators see the combined challenges of disease, pathogens (notably sea lice) and environmental load as a serious obstacle to further expansion of the industry (Christiansen et al. 2017).

\subsection{Iceland}

The main fish species farmed in Iceland are salmon, Arctic charr, and rainbow trout. Salmon aquaculture has grown significantly in recent years, although the Icelandic experience with salmon farming has been one of repeated expansion and retrenchment (Jóhannsdóttir 2016). The first large scale aquaculture initiatives in Iceland date back to the 1980s, with the establishment of land based farms for rearing of Atlantic salmon and smolt production for sea ranching. Although few of these initial attempts were successful, many of the larger fish farms are still in use, primarily producing Arctic charr. In the early 2000s, a second wave of salmon aquaculture investment occurred, primarily in the Eastern fjords. However, none of these attempts were successful due to both technical problems and the high value of the Icelandic currency at the time, which suppressed exports. A third wave of salmon aquaculture began around 2010, with salmon farms being established both in the Eastern and Western Fjord regions. Production has subsequently grown rapidly, from less than 300 tonnes in 2008 to over 11,000 tonnes in 2017. Current licences allow for 30,000 tonnes, but salmon companies have applied for expansions that could increase production to 70,000 tonnes in coming years (IAA 2018).

This rapid expansion of production has caught government regulatory and monitoring bodies unprepared. Regulations are still under development, and a committee consisting of representatives from the aquaculture sector, river owners, and government has recently drafted a policy document on regulatory control and oversight (MFA 2017). Among the proposals are the establishment of maximum thresholds for salmon production based on comprehensive risk assessments of environmental impact. The committee also made a number of other suggestions about licences, fees, monitoring and access to information on aquaculture. It is hoped that further 
regulatory development will mitigate disputes between supporters and opponents of the industry, but this remains to be seen.

The politics of aquaculture in Iceland have been strongly shaped by the involvement of private owners of rivers, who derive significant income from the recreational Atlantic salmon fishery (Jóhannsdóttir 2016). River owners and angler associations have been vocal in pressing for restrictions on salmon aquaculture, which they see as a threat to wild stocks (Intrafish 2017). Environmental groups have also entered the fray in recent years. All these groups have advanced concerns about genetic mixing of escaped farmed salmon with wild populations, sea lice transfer to wild fish, and organic and chemical pollution. They also point out that the broodstock used for aquaculture in Iceland originate from Norwegian populations and are therefore exotic. In 2004, in response to the potential threat of genetic mixing of cultured and wild fish, the Ministry of Agriculture announced that salmon farming would be forbidden in areas adjacent to the main rivers with native Atlantic salmon populations. This decision effectively restricted salmon farming to the Northwest- and East-fjord regions of the country.

\subsection{Norway}

Norway's aquaculture industry is dominated by salmon production, totalling 1.2 million tonnes per year (DoF 2017). The value of farmed salmon exports exceeded $\$ 8$ billion USD in 2016, constituting more than $70 \%$ of Norway's seafood exports. Over the past fifty years, aquaculture has grown at the highest rate of any sector of the Norwegian economy, expanding at an average annual rate of $10 \%$ (Hersoug 2015). In recent years, however, production volumes have been flat due to government decisions to restrict expansion over concerns about sea lice infection (DoF 2017). The government nonetheless has high ambitions for salmon aquaculture, aiming to triple production volume by 2030 (Hersoug 2015).

The Norwegian aquaculture management system is based on both licenses and site permissions. The government allocates licenses through its Directorate of Fisheries, while site permissions are granted in a process that is coordinated by local counties but also involves several government departments. In addition, coastal communities participate in aquaculture governance through their central role in marine spatial planning (Solås et al. 2015). Each of the 275 coastal municipalities are responsible for planning the usage of adjacent sea areas up to one nautical mile from the coastline (Johnsen and Hersoug 2014). Several government agencies may 
also contest coastal zone plans, including the Sami Parliament, which is the representative government body for the indigenous Sami people of Norway. This governance system has developed incrementally over the last 40 years, under different political regimes and addressing changing public concerns. The result is a complex system that has been criticized for its fragmented authority across scales and agencies (Solås et al. 2015; Robertsen et al. 2016; Osmundsen and Olsen 2017).

Public attitudes in Norway towards salmon aquaculture have generally been positive, but this has changed markedly over the last decade. Concerns about the environmental impact of the open cage production have become more salient, and media debates about the industry have turned more critical (Solås 2014). Key issues include the impacts of escapes on the wild salmon, the transmission of diseases and parasites, the impact of organic and chemical pollutants on the seabed and local ecosystems (Liu et al. 2011; Uglem et al. 2014). Other points of contention are the corporate concentration of aquaculture operations and consequent lack of local ownership, the modest local employment and economic benefits of this increasingly technology-intensive industry, and the spatial displacement of other users such as local fishermen and anglers (Sandersen \& Kvalvik, 2015). The Sami Parliament has expressed concern that current spatial plans leave insufficient space for traditional Sami fisheries, and that local knowledge about environmental impacts from salmon aquaculture is being ignored (Brattland 2010). Overall, this critical attention has led to increasing local opposition to the industry, particularly the establishment of new production sites. It is unclear how this shift in public attitudes will impact the ambitious government plans for expansion of the industry described above.

\subsection{Sweden}

Sweden's aquaculture industry is small but diverse. This is an entrepreneurial sector, with high numbers of both start-ups and bankruptcies dating back to the 1980s (Larsson, et al. 2009). Even today, most companies are small, with little investment or ownership interests from outside the country. Shellfish aquaculture companies produce approximately 2,300 metric tonnes of mussels annually, as well as small volumes of oysters (SCB, 2017). However, mussel and oyster farms are frequently opposed by cottagers and tourism operators on aesthetic grounds, particularly on Sweden's western coast (Olofsson \& Andersson, 2014). Rainbow trout is farmed in open cage systems, mostly in brackish water, although trout production has declined in recent 
years due to a combination of market and environmental challenges, particularly eutrophication in and around aquaculture sites (Wenblad et al. 2013).

A small number of open cage fish farms can be found on Sweden's west coast. The natural geography of the region, however, is limited and lack of appropriate space is an issue. Aquaculture operators have pressed for better marine spatial planning to better access available sites and reduce friction with other sectors and coastal users. Critics of aquaculture, which include environmental groups, some participants in the fisheries and tourism sectors, and some government regulators, point to issues such as eutrophication, disease transfer, and the impact of escapes on wild species as evidence of the need to restrict aquaculture expansion.

Given these social and ecological challenges, there is much discussion and interest in Sweden for Recirculating Aquaculture Systems (RAS). RAS systems have controlled interactions with the environment, and can be land-based and located away from coast and shorelines. There are currently two prototype land-based RAS farms in operation, one for Artic char and the other Atlantic salmon, respectively producing 4,000 and 6,000 tonnes annually. RAS technology has provided critics with a novel line of argumentation against traditional open cage aquaculture. Specifically, a regulation of the Swedish Environmental Protection Agency that stipulates that new or expanded business projects in the resource sector must use the best available technology. Critics have argued that this directive applies to aquaculture, and that RAS technology should be mandatory for new or expanded production sites. Indeed, environmental groups have threatened litigation against companies that do not adopt RAS technology in official applications for licenses. It remains to be seen if this argument carries weight in regulatory decision-making or in Swedish courts.

\section{Comparing aquaculture in five wealthy nations using political ecology}

As argued previously, political ecology is a flexible framework that is well suited for making comparisons across diverse natural and human environments. In this section, we present the results of the comparisons across the five nations that were achieved via the workshops and document reviews. Following the political ecology framework, this comparison emphasizes two sets of factors: (1) what we term "ecological-political factors," which refer to conditions or phenomena in the natural environment that directly affect political decisions and dynamics; and (2) what we term "political-ecological factors," which refer to social and political dynamics that 
directly affect aquaculture's imprint on the environment, territories, and human geographies. We analyze both factors with an eye to prospects for future expansion of aquaculture production across the cases.

\subsection{Ecological-political factors}

Aquaculture production in each of the five nations is impacted by a number of ecologicalpolitical factors, which are summarized in Table 1. In this table, judgements are made regarding the significance of these impacts on the prospects for expansion of aquaculture production on an ordinal scale (major impact, minor impact, no impact). These judgements are based on conclusions from the available academic literature, and on the collective assessment of the authorship group.

Many of the factors identified in Table 1 apply most directly to salmon aquaculture. Salmon aquaculture is the largest subsector across the five nations, by volume and value (excluding Sweden, which does not participate in salmon production). Salmon aquaculture is a knowledge-intensive, vertically-integrated, global-scale business that is dominated by a small number of large corporate actors. As such, salmon production methods are similar across the case nations, generating common environmental challenges. Disease and parasite control is a major challenge across the salmon farming industry, for example. Outbreaks of sea lice, as well as infectious diseases such as amoebic gill disease (AGD), infectious salmon anemia (ISA) and pancreas disease (PD) are also continuing risks for open cage salmon farming (McVicar 1997; Johansen et al. 2011). Common concerns also exist about escapes from salmon farming operations, benthic pollution from farm waste, and the more global impact of "fishing down food webs" in the Global South to produce meal for the husbandry of a carnivorous species (Pitcher and Lam 2010).

However, Table 1 also reflects the fact that there is substantial variation in the physical and ecological conditions across the cases, which lends the challenges facing each nation a specific character. In countries with native salmon populations, for example, there is significant concern about disease transfer between cultured and wild populations. This has been a major flashpoint in the Pacific region of Canada, for example. Pacific salmon populations have historically been robust, but these have recently shown signs of reduced survival and reproduction. There is disagreement over the causes of these changes, and a recent Judicial 
Inquiry of the Government of Canada identified warming waters, burgeoning predator populations, and changing ocean dynamics as key factors (Cohen 2012). Dissenting scientists and activists also point to salmon farming, particularly with respect to disease and sea lice transfer to migrating juvenile salmon (e.g., Morton et al. 2010).

Table 1 - Ecological-Political Factors Affecting Prospects for Expanded Aquaculture Production in the Case Nations

\begin{tabular}{|c|c|c|c|c|c|c|}
\hline & Canada & $\begin{array}{l}\text { Faroe } \\
\text { Islands }\end{array}$ & Iceland & Norway & Sweden & $\begin{array}{l}\text { Select } \\
\text { academic } \\
\text { literature }\end{array}$ \\
\hline Disease management for cultured fish health & Major & Major & Major & Major & Minor & $\begin{array}{l}\text { Lafferty et al. } \\
2015\end{array}$ \\
\hline Disease and pathogen transfer to wild stocks & Major & None & Major & Major & Minor & $\begin{array}{l}\text { Manning and } \\
\text { Hubley 2015; } \\
\text { Nygren and } \\
\text { Rikoon } 2008\end{array}$ \\
\hline Genetic harm to wild stocks & Major & None & Major & Major & None & $\begin{array}{l}\text { Bailey 2016; } \\
\text { Forseth et al. } \\
2017\end{array}$ \\
\hline Eutrophication / water quality & None & None & Minor & Minor & Major & $\begin{array}{l}\text { Bailey 2016; } \\
\text { Silver } 2010\end{array}$ \\
\hline $\begin{array}{l}\text { Natural geography (availability of } \\
\text { unexploited suitable environments) }\end{array}$ & None & Major & Minor & Minor & Major & $\begin{array}{l}\text { Hofherr and } \\
\text { Trujillo } 2015\end{array}$ \\
\hline $\begin{array}{l}\text { Political geography (ability to access } \\
\text { suitable environments) }\end{array}$ & Major & None & Major & Minor & Major & $\begin{array}{l}\text { Sandersen and } \\
\text { Kvalvik 2015; } \\
\text { Silver } 2010\end{array}$ \\
\hline
\end{tabular}

Countries with native populations must also manage the potential for genetic interactions between escaped Atlantic salmon and their wild counterparts. In the Atlantic region of Canada, wild Atlantic salmon populations have declined precipitously and several stocks are considered endangered and highly vulnerable (Bowlby and Gibson 2015). The recreational fishery for wild salmon in Iceland is considered to be sustainable, although concerns are being raised about genetic pollution and competition from escaped cultured salmon (Pórðardóttir and Guðbergsson 2017). In Norway, the health of wild salmon populations is highly variable, and therefore of 
concern to regulators. Genetic interaction with farmed salmon has been identified as a major threat to wild Altantic salmon stocks in that country (Forseth et al. 2017). In the Faroe Islands, in contrast, the lack of native salmon in Faroese rivers means that genetic pollution is not considered an obstacle to expansion. Similarly, disease and sea lice issues are seen predominantly as quality control problems on the farms themselves rather than as immanent threats to wild populations.

In addition to problems of environmental impact, lack of access to suitable environments is a significant ecological-political factor suppressing aquaculture expansion. In some nations, lack of access is due to natural conditions, in that ideal spaces simply do not exist or are already occupied. Open-cage aquaculture requires environments that are sheltered from weather and ocean swells but also have good water circulation and temperature profiles. In the Faroese case, the utilisation of all available space has become a tangible barrier to expansion and prompted exploration of more robust open-ocean technologies. In Sweden, recurring environmental problems such as eutrophication are similarly restricting opportunities to expand, although the technological push in this case is towards land-based RCA systems. In Norway, there is significant variation in spatial availability. While suitable areas remain along the northern coast, the south-western coast has been saturated. In other cases, however, suitable environments exist but are inaccessible to industry. In the cases of Canada and Iceland, for instance, access to suitable environments is restricted foremost via policy (more on this below), prompting companies and regulators to investigate prospects for increasing production from existing sites.

The lack of suitable environments also puts aquaculture into direct ecological contact with other fisheries, which can lead to conflict at the local level. In Norway, there is concern in some communities that salmon farms interfere with the spawning, abundance and quality of a range of species, including of cod, shrimp, and saithe. In the Faroe Islands and in the Atlantic region of Canada, there is concern about interactions between salmon farming and key invertebrate fisheries such as lobster (Walters 2007). A number of indigenous groups in Canada's Pacific region see benthic pollution from salmon farms as a threat to traditional shellfish harvesting (Heaslip 2008).

In summary, ecological-political factors present substantial challenges for future expansion of aquaculture across the five nations. These challenges emerge directly from biophysical variables (for instance, disease, pollution, and lack of appropriate environments) or 
from political attempts to manage or respond to ecological problems (as with geographic restrictions on aquaculture siting). Table 1 shows that many of these challenges are shared across the nations, suggesting that they originate in current methods of production and could be fruitfully addressed by industry-wide reforms. This is particularly the case for disease and pathogen issues. However, Table 1 also shows variability across the cases, such as the presence or absence of wild species, issues of water quality, and the effects of spatial overlap with other sectors. The particular nature of these ecological-political challenges mean that generic solutions are unlikely to apply in all cases, and industry and regulators should adopt country- and regionspecific approaches to mitigating these problems. This theme will be considered in detail in the conclusion.

\subsection{Political-ecological factors}

In addition to ecological-political factors, the comparison reveals a number of variables across the five nations that are primarily social and political in origin or expression, but that directly affect future prospects for aquaculture expansion (and are thus political-ecological in nature). These are summarized in Table 2.

First, regulatory overlap or complexity appears to be a significant issue in several of the case countries. In Norway, for example, a number of sector agencies are involved in aquaculture governance, including the Food Safety Authority, the Coastal Administration, the Directorate of Fisheries, and county governors. In the Faroe Islands, aquaculture is governed by four distinct government agencies, including the Ministry of Industry and Commerce, the Ministry of Health and Environment, and the Environment Agency, with the occasional involvement of the Fishery Inspection Agency and regional harbour authorities on questions of marine traffic safety.

There are also significant cross-jurisdictional issues in some nations. In Norway, local municipalities are involved in aquaculture governance via marine spatial planning processes. In addition, sector agencies have powers to veto aquaculture siting decisions, based on their authority in areas such as environment, fisheries, marine transport, and naval defense interests. Canada has similar challenges, primarily across federal and provincial scales. The federal government is responsible for regulating marine fisheries and ocean activities, while the provinces are responsible for natural resources, environmental regulation and monitoring, and business licensing. Both the federal and provincial governments must therefore approve 
aquaculture sites, although local governments are not directly involved in the approvals process and have no veto power. Further complicating matters, a recent court decision (Morton v. British Columbia, 2009) has led to the development of separate regulatory systems on the Pacific and Atlantic coasts, with the federal government assuming primary responsibility for the former (Doelle and Saunders 2016). These issues are largely absent in the Faroes, Iceland, and Sweden, which have greater jurisdictional clarity.

Table 2 - Political-Ecological Factors Affecting Prospects for Expanded Aquaculture Production in the Case Nations

\begin{tabular}{|c|c|c|c|c|c|c|}
\hline & Canada & $\begin{array}{l}\text { Faroe } \\
\text { Islands }\end{array}$ & Iceland & Norway & Sweden & $\begin{array}{l}\text { Select } \\
\text { academic } \\
\text { literature }\end{array}$ \\
\hline Regulatory overlap (across agencies) & Major & Major & Minor & Major & Minor & $\begin{array}{l}\text { Myklebust 2016; } \\
\text { Young and } \\
\text { Matthews 2010; }\end{array}$ \\
\hline Jurisdictional overlap (across scales) & Major & None & None & Minor & None & $\begin{array}{l}\text { Hersoug 2013; } \\
\text { Silver } 2010\end{array}$ \\
\hline $\begin{array}{l}\text { Legal uncertainty / absence of aquaculture } \\
\text { law }\end{array}$ & Major & None & None & None & Major & $\begin{array}{l}\text { VanderZwaag } \\
\text { and Chao 2006; } \\
\text { Bankes et al. } \\
2016 \text {; }\end{array}$ \\
\hline $\begin{array}{l}\text { Lack of comprehensive marine spatial } \\
\text { planning processes }\end{array}$ & Major & Major & Major & None & Major & $\begin{array}{l}\text { Hovik and Stokke } \\
\text { 2007; Manning } \\
\text { and Hubley } 2015\end{array}$ \\
\hline Uncertainty over indigenous rights & Major & None & None & Minor & None & $\begin{array}{l}\text { Brattland 2010; } \\
\text { Joyce and } \\
\text { Satterfield } 2010\end{array}$ \\
\hline Private ownership of aquatic spaces & None & None & Major & None & Minor & (None) \\
\hline $\begin{array}{l}\text { Public suspicion of foreign ownership and } \\
\text { control }\end{array}$ & Major & Major & Minor & Minor & None & $\begin{array}{l}\text { Young and } \\
\text { Matthews } 2010\end{array}$ \\
\hline $\begin{array}{l}\text { Lack of legitimacy (hegemony) for } \\
\text { aquaculture industry and policy }\end{array}$ & Major & Minor & Major & Minor & Major & $\begin{array}{l}\text { Hersoug 2015; } \\
\text { Phyne, } 2010\end{array}$ \\
\hline
\end{tabular}

Second, legal uncertainty exists in countries that have yet to enact aquaculture-specific legislation. This is the case in Sweden, where aquaculture opponents are using the generic policies and guidelines of the Swedish Environmental Protection Agency to contest aquaculture 
expansion through court challenges. In Canada, aquaculture is governed primarily under a federal Fisheries Act, leading to significant uncertainty about the role and place of aquaculture in the regulatory mix. This contrasts with Norway, Iceland, and the Faroe Islands, where legislation specific to aquaculture has been developed. Still, some uncertainty remains in Norway related to overlapping authority when it comes to environmental issues (Myklebust 2016), as well as unresolved indigenous rights to coastal spaces (Brattland 2010). Furthermore, in Iceland, Sweden, and Canada, the absence of consistent policies for marine spatial planning has been identified as a major barrier to aquaculture expansion, as it leads to uncertainty about access to potential aquaculture sites (Ricketts and Hildebrand 2011).

Third, there is variation in rights regimes across the five nations. In Canada, the Faroes, and Norway, for example, fresh and marine waters (including lakes, riverbanks and intertidal zones) are controlled by governments, thus giving them greater authority and latitude for granting or restricting access to various user groups, including aquaculture. In Iceland, in contrast, private ownership of rivers used for recreational fisheries has provided a basis for collective action against aquaculture development, in the form of coalitions between property owners, anglers, and environmental groups. The rights of private property holders are a serious obstacle in this case (Jóhannsdóttir 2016).

Uncertainty about indigenous rights is also a factor in some countries, while being absent in others. In Canada, the rights of indigenous groups over traditionally-used territories are increasingly recognized in court decisions, forcing senior governments to consult with indigenous communities about economic decisions in these marine and terrestrial spaces (Newman 2009). Some aquaculture companies have partnered directly with indigenous communities through agreements on enhanced environmental monitoring and employment opportunities (Young and Liston 2010). However, a larger number of indigenous groups are opposed to salmon farming in traditional territories and have organized protest activities against them. While indigenous groups do not have veto powers, their opposition is logistically and symbolically formidable. In 2017, for example, indigenous groups in the Broughton Archipelago region of Canada's Pacific coast physically occupied two salmon farms for several months, demanding their removal. In Norway, the Sami Parliament has the right to object to aquaculture siting as part of the coastal zone planning process. While this not a direct veto, it grants indigenous groups significant influence over use of coastal space in northern areas with Sami 
populations (Johnsen and Hersoug 2014). Given that the vast majority of remaining suitable environments are found in these regions, there is concern among Sami leaders that government plans for aquaculture expansion may disproportionately affect their communities (Sametinget 2016).

Fourth, there is variation in the level of suspicion of foreign involvement or ownership of aquaculture operations. By restricting foreign ownership, the Faroe Islands have mitigated a key controversy that currently exists in Canada regarding the role of distant multinational firms. These are often portrayed by opponents as uncaring or dismissive of local concerns, particularly with respect to local culture and environments (Phyne 2010). The Faroese government has also sought to distribute the economic benefits of aquaculture production across multiple regions. This contrasts with the distinctively laissez-faire approach to economic geography taken by Canadian and Icelandic governments, which have taken no action on ownership and have permitted industry to concentrate in a few key service hubs (Young and Matthews 2010). These issues are observable even in Norway. On the one hand, suspicion is mitigated because Norwegian-owned or -managed firms are dominant at the global scale. On the other hand, concerns remain about the lack of distributed benefits. Local opponents sometimes label large Norwegian firms as "foreign" due to the lack of local ownership and ambivalence towards communities. These themes have been exacerbated since 2015, when the Norwegian government retracted a policy that no company could control more than $15 \%$ of all licenses without special permission, following pressure from the European Union.

Finally, our comparison reveals important differences in the degree of political legitimacy or hegemony enjoyed by the industry relative to other sectors, particularly those that may object to the presence of aquaculture in coastal waters. In Norway, for example, aquaculture now constitutes more than $70 \%$ of the total value of seafood exports - a role reversal from several decades ago when capture fisheries were dominant. Consequently, Norwegian policies and scientific research budgets are now predominantly oriented towards aquaculture - and more specifically salmon farming - giving the industry significant political resources and legitimacy within the relevant Ministries of government (Liu et al 2011; Hersoug 2015). This hegemony is similarly observable in the Faroe Islands, due again to the economic dominance of aquaculture production and exports. In Canada, Iceland, and Sweden, however, aquaculture remains a comparatively minor industry compared to others that operate in the same geographies. In 
Sweden, for example, aquaculture development has faced difficult opposition from tourism operators that object to the newcomer on the aesthetic landscape. Opposition also exists in Iceland from the angling sector that is particularly lucrative for some landowners. In Canada, federal and provincial governments have established a wide range of direct and indirect subsidies to the aquaculture sector, including large investments in research, favourable regulatory changes, and international marketing on behalf of the industry (Young and Matthews 2010). However, the commercial fishing sector is still a substantial employer on both the Atlantic and Pacific coasts, and has deep roots in many communities (Ommer 2007). In this case, the hegemony of traditional fisheries, while weakened, continues to have significant influence in government agencies and local communities.

\section{Conclusions}

Aquaculture production has grown rapidly in recent decades and now plays a major role in the global food system. In developed countries, however, growth has slowed significantly due to a number of social-ecological challenges and subsequent disagreements over the place and potential of aquaculture in national and regional economies. This article has used a political ecology framework to comparatively examine key similarities and differences in the character and severity of these challenges across five wealthy nations - Canada, the Faroe Islands, Iceland, Norway, and Sweden. Political ecology examines the intersection of natural and human systems and phenomena, making it an important tool for understanding conflicts over natural resources. According to this perspective, ecological issues become political issues, and vice versa, due to human decisions about the governance of people and environments. The framework allows for nuanced analysis of challenges that may originate in either biophysical or social conditions, but have direct implications across the (nominal) human-nature divide.

The analysis identified a number of social-ecological factors currently limiting growth in the case nations. Some of these factors are found across the countries examined, while others reflect the unique ecological and/or socio-political conditions, decisions, and compromises occurring in each. From a governance perspective, much can be learned from these similarities and differences. For example, common challenges offer opportunities for cross-national learning and the development of best practices. This is particularly salient in the domains of disease and pathogen management, which are major concerns in all nations where salmon aquaculture is 
practiced. Monitoring and reporting of disease and pathogen prevalence are required in all countries, but the requirements in terms of testing intervals, public disclosure of information, and thresholds for mitigation and remedial action vary substantially. The burden of learning and coordination should not be on national governments alone, however. Industry itself could serve as a vehicle for more universal adoption of best practices by voluntarily adhering to the most stringent monitoring and reporting regimes regardless of jurisdiction, an approach that may in turn enhance public confidence in the sector.

The observed differences across the cases also yield important policy lessons. For instance, nations that lack clear regulatory regimes anchored in legislation specific to aquaculture face a number of avoidable obstacles. The absence of an Aquaculture Act or similar legislation means that regulation of the sector relies on law that was not designed to address the particular needs or demands of the industry, particularly on questions of the rights and obligations of producers, access to and enclosure of marine space, and jurisdictional authority. These gaps invite recurring legal challenges that in turn often muddy the waters, as evident in the Canadian case that has led to the establishment of separate regulatory regimes in the Atlantic and Pacific regions. For law-makers, the lesson should be clear: an industry as large, novel, and disruptive as aquaculture requires a specific legislative framework as a basis for long-term, sustainable growth.

Another important policy lesson derived from the observed differences, is that gaps in related policy fields can have a strong impact on aquaculture development. For example, the absence of comprehensive marine spatial planning processes in several nations - notably in Canada, Iceland, and Sweden - has hindered aquaculture expansion and likely fuelled conflict among coastal sectors and stakeholders. Norway's system of locally-driven marine spatial planning grants a measure of legitimacy to the decisions reached, including decisions about aquaculture siting. This legitimacy is not conferred when siting decisions are made ad hoc or on a case-by-case basis, are negotiated directly with an applicant or industry, and are reached without the participation of local communities. Similarly, aquaculture expansion is being held back in countries where there is uncertainty over rights, be they the rights of private property holders whose value may be impinged by the presence of aquaculture (as in Iceland and Sweden) or the more fundamental issue of indigenous rights over the activities that occur in traditional territories (as in Canada and Norway). The challenges here are both legal and procedural. Clear 
laws that define and delineate how property and indigenous rights apply in marine environments are essential. However, coordinated and agreed-upon processes for consulting and involving rights holders in aquaculture decisions are also important. Norway's system for involving the Sami Parliament in decision-making is imperfect, but is far more inclusive than the (non)systems that currently exist in Canada, Iceland, and Sweden, in which rights holders mobilize in the style of social movements with the aim of applying political and legal pressure to further their views and interests. The lesson here is that uncertainty in the broader policy environment imposes significant costs on all actors - industry, regulators, and stakeholders. At best, uncertainty creates confusion. At worst, it creates the impression among stakeholders (justified or not) that that decisions about aquaculture are being made behind closed doors, in the absence of standard evaluation criteria, and without their participation.

The findings from this research and the lessons derived from them are preliminary, and signal the need for more coordinated international comparative research on aquaculture. This article, and the workshops upon which it is based, are intended as a first step in this direction, but more is needed. A comprehensive research agenda, guided by common research questions, methods, and instruments, would further nuance these findings and provide concrete policy recommendations for industry, stakeholders, and governments alike. In the absence of such a research effort, it is likely that the profound social-ecological challenges facing aquaculture development will continue to be addressed in incremental, piecemeal fashion. The limitations to growth confronting this sector are serious and vexingly stubborn. Overcoming them demands a more coordinated research and communications approach so that lessons learned in one part of the world can be shared, adapted, and used in many others.

\section{References}

Atkinson, A. (1991). Principles of Political Ecology. London: Bellhaven.

Bankes, N., Dahl, I., \& VanderZwaag, DL. (2016). Aquaculture Law and Policy: Global, Regional and National Perspectives. Northampton, MA: Edward Elgar.

Barton, JR., \& Floysand, A. (2010) The political ecology of Chilean salmon aquaculture. Global Environmental Change, 20(4), 739-752.

Belskey, J. (2002). Beyond the Natural Resource and Environmental Sociology Divide: Insights from a transdisciplinary perspective. Society and Natural Resources, 15, 269-280. 
Bennett, CJ., \& Howlett, M. (1992). The lessons of learning: reconciling theories of policy learning and policy change. Policy Sciences, 25(3), 275-294.

Bennett, N. et al. (2017). Conservation social science: understanding and integrating human dimensions to improve conservation. Biological Conservation, 205, 93-108.

Biersack, A. (2006). Reimagining political ecology: culture/power/history/nature. In A. Biersack \& B. Greenberg (Eds.), Reimagining Political Ecology (pp. 3-40). Durham: Duke University Press.

Bowlby, HD., \& Gibson, AJF. (2015). Environmental effects on survival rates: robust regression, recovery planning and endangered Atlantic salmon. Ecology and Evolution, 5(16), 34503461 .

Brattland, C. (2010). Mapping rights in coastal Sami seascapes. Arctic Review, 1(1), 28-53.

Bush, SR., \& Marschke, MJ. (2014). Making sense of aquaculture transitions. Ecology and Society, 19(3), 50-62.

Christiansen, P. Steingrund, M. Galbraith, Ø. Patursson. (2015). Abundance and distribution of planktonic Lepeophtheirus salmonis and Caligus elongatus in a fish farming region in the Faroe Islands. Aquaculture Environment Interactions, 7, 15-27.

Cohen, BI. (2012). The Uncertain Future of Fraser River Sockeye: Volume 2, Causes of the Decline. Commission of Inquiry into the Decline of Sockeye Salmon in the Fraser River. URL: http://www.cohencommission.ca/en/FinalReport/

Cohen, A., \& Bakker, K. (2014). The Eco-Scalar Fix: Rescaling Environmental Governance and the Politics of Ecological Boundaries in Alberta, Canada. Environment and Planning D: Society and Space, 32(1), 128-146.

Deutsch, L., Graslund, S., Folke, C., Troell, M., Huitric, M., Kautsky, N., \& Lebel, L. (2007). Feeding aquaculture growth through globalization: Exploitation of marine ecoystems for fishmeal. Global Environmental Change, 17(2), 238-249.

DFO. (2015). 2015 Canadian Aquaculture Production Statistics. Ottawa, ON: Government of Canada.

Doelle, M. \& Saunders, P. (2016) Aquaculture governance in Canada: a patchwork of approaches. (Pp. 183-212) In Bankes, N., Dahl, I., \& VanderZwaag, DL. (eds) (2016). Aquaculture Law and Policy: Global, Regional and National Perspectives. Northampton, MA: Edward Elgar. 
DoF (2017). Akvakulturstatistikk (tidsserier). Directorate of Fisheries. URL:

https://www.fiskeridir.no/Akvakultur/Statistikk-akvakultur/Akvakulturstatistikk-tidsserier

Escobar, A. (2010). Postconstructivist political ecologies. In M. R. Redclift \& G. Woodgate

(Eds.), The International Handbook of Environmental Sociology (pp. 91-105).

Northhampton MA: Edward Elgar.

FAO. (2016). The State of the World's Fisheries and Aquaculture 2016. Rome, Italy: Food and Agriculture Organization of the United Nations.

Fazey, I., et al. (2012). Knowledge exchange: a review and research agenda for environmental management. Environmental Conservation, 40(1), 19-36.

Forseth, T., et al. (2017). The major threats to Atlantic salmon in Norway. ICES Journal of Marine Science, 74(6), 1496-1513.

Forsyth, T. (2004). Critical Political Ecology: the Politics of Environmental Science. New York: Routledge.

Heaslip, R. (2008). Monitoring salmon aquaculture waste: The contribution of First Nations' rights, knowledge, and practices in British Columbia, Canada. Marine Policy, 32(6), 988996.

Hersoug, B. (2013). The battle for space: The position of Norwegian aquaculture in integrated coastal zone planning. In Moksnes, Dahl and Strøttrup (Eds.): Global challenges in Integrated Coastal Zone Management. P: 159- 168

Hersoug, B. (2015). The greening of the Norwegian salmon production. Maritime Studies. 14(1): $1-16$.

Hersoug, B, Karlsen, KM., Solås, AM., Kvalvik, I., Johnsen, JP., Young, N. \& Brattland, C., Schreiber, D., Simonsen, K., Olofsson, E. and Thorarensen, H. (2017). Intensive aquaculture and sustainable regional development in the Arctic region - from controversy to dialogue (AquaLog). Nofima report 13/2017.

Hofherr, J, Natale, F, \& Trujillo, P. (2015). Is lack of space a limiting factor for the development of aquaculture in EU coastal areas?. Ocean \& Coastal Management, 116, 27-36.

Hovik, S., \& Stokke, KB. (2007). Balancing aquaculture with other coastal interests: a study of regional planning as a tool for ICZM in Norway. Ocean \& Coastal Management, 50(11-12), 887-904. 
Howlett, M., \& Brownsley, K. (Eds.). (2008). Canada's Resource Economy in Transition.

Toronto: Emond Montgomery.

IAA [Iceland Aquaculture Association] 2018. Salmon aquaculture. URL :

http://www.lf.is/is/fiskeldi-a-islandi-2/laxeldi/

IntraFish (2017). A tough opponent in Iceland. URL :

https://www.intrafish.no/nyheter/1310624/en-krevende-motstander-paa-island

Jacobsen, H. (2011). Ringar í sjónum, Søgan um føroysku alivinnuna. Havbúnaðarfelagið.

Torshavn: Faroe Islands.

Jóhannsdóttir, A. (2016). Iceland: aspects of the legal environment relating to aquaculture. (Pp.

266-288). In Bankes, N., Dahl, I., \& VanderZwaag, DL. (eds) (2016). Aquaculture Law and

Policy: Global, Regional and National Perspectives. Northampton, MA: Edward Elgar.

Johansen, LH., Jensen, I., Mikkelsen, H., Bjørn, PA., Jansen, PA., \& Bergh, Ø. (2011). Disease interaction and pathogens exchange between wild and farmed fish populations with special reference to Norway. Aquaculture, 315(3), 167-186.

Johnsen, JP., \& Hersoug, B. (2014). Local empowerment through the creation of coastal space? Ecology and Society, 19(2). 1-7.

Joyce, AL., \& Satterfield, TA. (2010). Shellfish aquaculture and First Nations' sovereignty. Natural Resources Forum, 34(2),106-123.

Karlsen, KM., Andreassen, O., \& Hersoug, B. (2015). From controversy to dialog in aquaculture. Nofima report 33/2015.

Keller, BC. \& Leslie, RM. (1996) Sea Silver. Vancouver: Horsdal \& Schubart

Krkošek, M., Ford, JS., Morton, A., Lele, S., Myers, RA., \& Lewis, MA. (2007). Declining wild salmon populations in relation to parasites from farm salmon. Science, 318(5857), 17721775.

Lafferty, KD. et al. (2015). Infectious diseases affect marine fisheries and aquaculture economics. Annual Review of Marine Science, 7, 471-496.

Larsson, H., Lundh, N. \& Nilsson, J. (2009). Det växande vattenbrukslandet. SOU 2009:26. ISBN 978-91-38-23166-1. Edita Sverige AB, Sweden. URL: http://www.regeringen.se/49bbac/contentassets/72c9baed4fad499fa4dade6978951a88/detvaxande-vattenbrukslandet-sou-200926 
Liu, Y.; Olaussen, JO. \& A. Skonhoft (2011). Wild and farmed salmon in Norway-A review. Marine Policy 35(3), P. 413-418

Manning, F., \& Hubley, E. (2015). Aquaculture Industry in Canada: Standing Senate Committee on Fisheries and Oceans. Ottawa, ON: Senate of the Government of Canada.

McVicar, A. H. (1997). Disease and parasite implications of the coexistence of wild and cultured Atlantic salmon populations. ICES Journal of Marine Science, 54(6), 1093-1103.

MFA. (2017). Skýrsla starfshóps sjávarútvegs- og landbúnaðarráðherra um stefnumótun í fiskeldi. Icelandic Ministry of Fisheries and Aquaculture. URL: www.stjornarradid.is/lisalib/getfile.aspx?itemid=9d0e56b5-87fa-11e7-9419-005056bc4d74

Morton, A., Routledge, R., McConnell, A., \& Krkošek, M. (2010). Sea lice dispersion and salmon survival in relation to salmon farm activity in the Broughton Archipelago. ICES Journal of Marine Science, 68(1), 144-156.

Myklebust, IE. (2016). Aquaculture law and administration in Norway. In Banks, N, Dahl, I. \& DL VanderZwaag (Eds.): Aquaculture Law and Policy: Global, Regional and National Perspecives. Cheltenham, UK: Edward Elgar Publishing. 336-359.

Neumann, R. P. (2005). Making Political Ecology. New York: Routledge.

Newman, DG. (2009). The Duty to Consult: New Relationships with Aboriginal Peoples. UBC Press, Vancouver.

Nygren, A., \& Rikoon, S. (2008). Political ecology revisited: integration of politics and ecology does matter. Society and Natural Resources, 21, 767-782.

Olofsson, E. \& Andersson. J. 2014. Spatial planning guidelines for Baltic Sea Region aquaculture. Finnish Game and Fisheries Research Institute: Helsinki, Finland.

Ommer, R. (2007). Coasts Under Stress. Montreal: McGill-Queen's University Press.

Osmundsen, TC. \& Olsen, MS. (2017). The imperishable controversy over aquaculture. Marine Policy. 76, 136-142

Peet, R., Robbins, P., \& Watts, MJ. (2011). Global Political Ecology. New York: Routledge. Phyne, J. (2010). A comparative political economy of rural capitalism: Salmon aquaculture in Norway, Chile and Ireland. Acta Sociologica, 53(2), 160-180.

Pitcher, T., \& Lam, M. (2010). Fishful thinking: rhetoric, reality, and the sea before us. Ecology and Society, 15(2). 1-12.

Pórðardóttir, G., Guðbergsson, G. 2017. Catch statistics for Atlantic salmon Arctic charr and 
brown trout in Icelandic rivers and lakes 2016. Marine and Freshwater Research in Iceland,

Report no. HV 2017-030.

Ricketts, P. J., \& Hildebrand, L. (2011). Coastal and ocean management in Canada: progress or paralysis? Coastal Management, 39(1), 4-19.

Robbins, P. (2012). Political Ecology (2nd ed.). Malden, MA: Wiley-Blackwell.

Robertsen, R., Andreassen, O., Hersoug, B., Karlsen, KM., Osmundsen, T., Solås, AM., Sørgård, B., Asche, F., Tveterås, R. (2016). Regelrett eller rett regel? Håndtering og praktisering av regelverket for havbruksnaringen. Nofima report 37/2016.

Rudd, M. et al. (2011). Generation of priority research questions to inform conservation policy and management at a national level. Conservation Biology, 25(3), 476-484.

Sandersen, H. \& Kvalvik, I. (2015). Access to aquaculture sites: A wicked problem in Norwegian aquaculture development. Maritime Studies, 14(1), 1-9.

Sametinget (2016). Sametingsmelding om areal og milj $\phi$. Karasjok. 47 pp

SCB, 2017. Aquaculture in Sweden in 2016. Helen Stoye, Statistics Sweden. URL: http://www.scb.se/contentassets/6601e5cad8fa42b39eeee9db13dd1bdf/jo1201_2016a01_sm _jo60sm1701.pdf

SFI (2017). Statistics Faroe Islands. URL: www.hagstova.fo.

Silver, JJ. (2010). Seeking Certainty: A Political Ecology of Shellfish Aquaculture Expansion on the West Coast of Vancouver Island, British Columbia (PhD Thesis). Simon Fraser University, Burnaby, BC.

Solås, AM. (2014) En regjerlig kyst? Kunnskap og politikk i kystsoneplanlegging (PhD Thesis). UiT- the Arctic University of Norway.

Solås, AM., Hersoug B., Andreassen, O., Tveterås, R., Osmundsen, TC., Sørgård, B., Karlsen, KM., Asche, F., Robertsen, R. (2015). Rettslig rammeverk for norsk havbruksnaring Kartlegging av dagens status. Nofima report 29/2015.

Turner, M. D. (2014). Political ecology I: an alliance with resilience? Progress in Human Geography, 38(4), 616-623.

Uglem, I.; Karlsen, Ø.; Sanchez-Jerez; P. \& Sæther, BS. (2014). Impacts of wild fishes attracted to open-cage salmonid farms in Norway. Aquaculture Environment Interactions, 6, 91-103

VanderZwaag, DL., \& Chao, G. (Eds.). (2006). Aquaculture Law and Policy: Towards principled access and operations. Routledge: New York 
Walker, PA. (2005). Political ecology: where is the ecology? Progress in Human Geography, $29(1), 73-82$.

Walters, BB. (2007). Competing use of marine space in a modernizing fishery: salmon farming meets lobster fishing on the Bay of Fundy. Canadian Geographer, 51(2), 139-159.

Wenblad, A., Jokumsen, A., Eskelinen, U., Torrissen, O., (2013). Background paper on aquaculture research. Mistra: Stockholm. URL: http://www.mistra.org/wpcontent/uploads/2018/01/Mistra-Aquaculture.pdf

Young, N. (2015). Environmental Sociology for the Twenty First Century. Don Mills, ON: Oxford University Press.

Young, N., \& Liston, M. (2010). (Mis)managing a risk controversy: The Canadian salmon aquaculture industry's response to organized and local opposition. Journal of Risk Research, 13(8), 1043-1065.

Young, N., \& Matthews, R. (2010). The Aquaculture Controversy in Canada: Activism, policy, and contested science. Vancouver: UBC Press.

Zhou, X. (2017). An overview of recently published global aquaculture statistics. Rome: FAO. 